\title{
Phenotypic and molecular assessment of antimicrobial resistance profile of airborne Staphylococcus spp. isolated from flats in Kraków
}

\author{
Anna Lenart-Boroń $(\mathbb{D} \cdot$ Katarzyna Wolny-Koładka • Katarzyna Juraszek • \\ Andrzej Kasprowicz
}

Received: 15 November 2016/Accepted: 4 April 2017/Published online: 10 April 2017

(C) The Author(s) 2017. This article is an open access publication

\begin{abstract}
Bacteria of the genus Staphylococcus were isolated from air sampled from living spaces in Kraków (Poland). In total, 55 strains belonging to the genus Staphylococcus were isolated from 45 sites, and 13 species of coagulase-negative staphylococci were identified. The species composition of studied airborne microbiota contains Staphylococcus species that are rarely infectious to humans. Most commonly isolated species comprised S. hominis and S. warneri. The disk-diffusion tests showed that the collected isolates were most frequently resistant to erythromycin. The PCR technique was employed to search for genes conferring the resistance in staphylococci to antibiotics from the group of macrolides, lincosamides and streptogramins. The analyzed Staphylococcus isolates possessed simultaneously 4 different resistance genes. The molecular analysis with the use of specific primers allowed to determine the
\end{abstract}

A. Lenart-Boroń $(\bowtie) \cdot K$. Wolny-Koładka

Department of Microbiology, University of Agriculture, Mickiewicza Ave. 24/28, 31-059 Kraków, Poland e-mail: a.lenart-boron@ur.krakow.pl

K. Juraszek

Faculty of Biotechnology and Horticulture, University of Agriculture, 29 Listopada Ave 54, 31-425 Kraków, Poland

A. Kasprowicz

Centre for Microbiological Research and Autovaccines,

Sławkowska 17, 31-016 Kraków, Poland

e-mail: a.kasprowicz@cbm.com.pl most prevalent gene which is $m p h C$, responsible for the resistance to macrolides and for the enzymatic inactivation of the drug by phosphotransferase. The second most often detected gene was $m s r A l$, which confers the resistance of staphylococci to macrolides and is responsible for active pumping of antimicrobial particles out of bacterial cells.

Keywords Antibiotics - Bacteria - Molecular characterization - Polymerase chain reaction (PCR) . Resistance

\section{Introduction}

Nowadays, people spend increasingly more time indoors but these places often do not meet the indoor air quality standards. Indoor environment is frequently conquered by pathogenic and drug-resistant microorganisms, hazardous to the health and life of residents (Górny and Dutkiewicz 2002). The major source of airborne microbiological contamination in living spaces is usually people emitting microorganisms during processes such as talking, coughing, sneezing and desquamation. Another important factor affecting the composition of airborne microflora is the process of microbial migration from the outdoor environment, which is of a particular importance during summer and autumn when buildings are naturally ventilated (Butarewicz 2005). Significant internal sources of 
bioaerosols include also pets, whose hair may constitute a factor of pathogen transmission (Jo and Kang 2006). Pathogenic microorganisms in flats may also dwell in surface linings and construction materials, such as wallpaper, insulating materials, plasterboards and many others. Microbiological air pollution is also favored by the increasing presence of air conditioners, fans and heating systems that are ideal place for dwelling, proliferation and subsequent spreading of microorganisms (Gąska-Jędruch and Dudzińska 2009).

Among bioaerosol-forming bacteria, special attention should be paid to the genus Staphylococcus, which colonizes humans and animals. Staphylococci colonize mainly skin, epithelia and mucous membranes, in particular moist areas of nose, armpits and in groins (Irving et al. 2008). Bacteria from the genus Staphylococcus can survive for a long period of time in the air, easily being transferred and contaminating the environment. Within this genus, the most important etiological factors of human infections are S. aureus, $S$. epidermidis, S. saprophyticus (Bartoszewicz-Potyrała and Przondo-Mordarska 2002) and S. haemolyticus (Botelho et al. 2012), which are often found in indoor air (Botelho et al. 2012; Hospodsky et al. 2012). Majority of current bioaerosol research is focused on the microbiological analysis of the air quality, taking into consideration only the total number of bacteria and, based on that, assigning different classes of air purity. Also the assessment of antimicrobial resistance of aerosol-forming bacteria which may pose epidemiological risk is often neglected.

Today, the most frequently identified mechanisms of antimicrobial resistance in the genus Staphylococcus are: enzymatic inactivation of antibiotic molecules involving hydrolases and transferases; changing affinity for a drug or duplication of functions of the target site as a result of mutation within the gene encoding the protein being the target site for an antimicrobial agent (which may cause reduction in its binding affinity) and active removal of an antimicrobial agent from the cell with the so-called "efflux mechanism" (CDC 2002). The most common mechanism of resistance to the antibiotics analyzed within this study, i.e., macrolides, lincosamides and streptogramins, involves posttranscriptional modification of ribosomal 23S rRNA as a result of the activity of adenino-N6methyltransferase. Structural genes encoding methyltransferase in different bacterial species are most commonly called erm (erythromycin ribosome methylation). Modification of 23S rRNA by methyltransferases causes the formation of multiple resistance in bacteria, as it inhibits three groups of antibioticsmacrolides, lincosamides and group B streptogramins $\left(M L S_{B}\right)$. This type of resistance may be encoded on plasmids or bacterial chromosomes, e.g., by a Staphylococcus aureus plasmid pE194, whose resistance may be either constitutive or inducible (Leclerq 2002). Another type of macrolide resistance is based on enzymatic inactivation of antibiotics, which can result from cleavage of macrolide lactone rings by esterase, or modification of its structure by enzymes from the group of transferases and by phosphorylase and hydrolase. These mechanisms confer the bacterial resistance only to one from three classes of the MLS group of antibiotics, e.g., genes vat or $v a t B$ in staphylococci encode acetyltransferase inactivating group A streptogramins (Stogios et al. 2014). Bacterial resistance to erythromycin is mainly dependent on the ability of antibiotics to overcome the bacterial cell envelope barriers, which is based on passive diffusion. Bacteria that are naturally resistant to antibiotics are characterized by high susceptibility to macrolides. The concentration of macrolides inside the cell of a susceptible Staphylococcus strain is a hundred times greater than in the naturally resistant bacteria. Erythromycin is a weak base, and its ionization decreases with increasing $\mathrm{pH}$, and its non-ionic form much easier penetrates the outer membrane. If the antibiotic reaches the interior of the cell, it is possible that a third type of resistance mechanism is revealed, which involves its active removal from the cell. Bacterial genes involved in this process include, e.g., msrA, $m s r B$ or $v g a$. These genes encode families of $\mathrm{ABC}$ transporters (multiprotein transport systems, ATPbinding cassettes) (Chesneau et al. 2005; Markiewicz and Kwiatkowski 2012).

This research was aimed at isolation of airborne staphylococci from living spaces, their species identification, phenotypic evaluation of their resistance to the selected groups of antimicrobial agents and detection of some of the resistance-conferring genes. The obtained results should help to determine the possible contamination of living spaces by pathogenic species of the Staphylococcus genus, and to assess-in the case of infection-whether the antibiotic administration could be effective in decreasing adverse health outcome appearance among exposed individuals. 


\section{Material and methods}

\subsection{Air sampling}

Bacteria from the genus Staphylococcus were isolated from the air of 45 randomly chosen flats in Kraków. The flats were selected based on their location (city center), floor area (between 30 and 60) and the number of residents (between 2 and 4). Air sampling was conducted twice per year-in spring (mid-April 2015) and winter (mid-January 2016). The measurements were taken in triplicates using MAS-100 air sampler (Merck) on working days in the afternoons (when the residents were present). Each time $100 \mathrm{~L}$ of air was sampled within $1 \mathrm{~min}$, in accordance with the requirements specified in the standard PN-Z-04008-08:1989 (1989). The air sampler was placed $1.5 \mathrm{~m}$ above the floor (one sampling site per each flat) in the center of the living room. Chapman medium (Biocorp, Poland) was used in order to isolate bacteria from the genus Staphylococcus. After sampling, the Petri plates were immediately transported to the laboratory where they were incubated at $36 \pm 1{ }^{\circ} \mathrm{C}$ for $48 \mathrm{~h}$.

\subsection{Isolation of pure cultures of staphylococci}

Species identification of the collected Staphylococcus isolates was carried out according to the methodology given by Kloos and Schleifer (1975), Kloos and Bannerman (1994), Gaillot et al. (2000), Murray (2007) and Lenart-Boroń et al. (2016). Pure cultures of Staphylococcus spp. were obtained by streaking of macroscopically characterized colonies which grew on the Chapman medium. Subsequently, Gramstained smears were microscopically observed, and the furazolidone susceptibility test was performed in order to discriminate the Staphylococcus genus from the Micrococcus strains. Furazolidone-susceptible strains were classified as Staphylococcus spp., while the resistant ones-as Micrococcus spp. Then, the catalase test was conducted to exclude the presence of catalase-negative streptococci in the analyzed material. Next, using free coagulase, the differentiation within the genus Staphylococcus was made to separate coagulase-positive and coagulase-negative species. The final stage of phenotypic identification was biochemical tests conducted using the API Staph system (bioMerieux).

\subsection{Antimicrobial resistance, disk-diffusion method}

In order to investigate the susceptibility of the Staphylococcus spp. isolates to antibiotics most commonly used in treatment, disk-diffusion tests were conducted on Mueller-Hinton Agar II (bioMerieux) with the use of the following antimicrobial agents: cefoxitin (FOX $30 \mu \mathrm{g}$ ), ciprofloxacin (CIP $5 \mu \mathrm{g}$ ), erythromycin (E $15 \mu \mathrm{g}$ ), gentamycin (CN $10 \mu \mathrm{g}$ ), clindamycin (DA $2 \mu \mathrm{g}$ ), tetracycline (TE $30 \mu \mathrm{g}$ ) and trimethoprim/sulfamethoxazole (SXT 1.25/23.75 $\mu \mathrm{g}$ ). The susceptibility evaluation was performed according to the guidelines of the National Reference Centre for Antimicrobial Susceptibility (KORLD), contained in the "Recommendations for the selection of tests for susceptibility and chemotherapeutics testing. Determination of susceptibility of Gram-positive cocci from the genus Staphylocococcus 2010" (Żabicka and Hryniewicz 2010).

Methicillin-susceptible S. aureus ATCC 25923 and methicillin-resistant $S$. aureus MR reference strains from the collection of the Jan Bober Centre of Microbiological Research and Autovaccines in Kraków were used as controls, and the results were interpreted according to the recommendations of KORLD and EUCAST (Hryniewicz 2014).

\subsection{Determination of genes conferring the resistance to MLS group antibiotics}

DNA extraction from pure cultures of staphylococci was performed using the Genomic Mini kit (A\&A Biotechnology, Poland), following the instructions provided by the manufacturer. Then, PCR amplification with specific primers (Table 1) was used to search for 17 genes conferring different mechanisms of resistance in bacteria from the genus Staphylococcus to antibiotics from groups of macrolides, lincosamides and streptogramins. The reactions were performed in a T100 thermal cycler (BioRad, USA), under temperature conditions optimal for the respective primers (Table 1). All PCRs were performed in a volume of $25 \mu \mathrm{L}$ containing $50 \mathrm{ng}$ of DNA template, $12.5 \mathrm{pM}$ of each primer, $2.5 \mathrm{mM}$ of dNTP, $1 \times$ PCR buffer and $1 \mathrm{U}$ DreamTaq DNA polymerase (ThermoScientific, USA).

The products were visualized by electrophoresis in $1 \%$ agarose gel in TBE buffer, stained with SimplySafe 


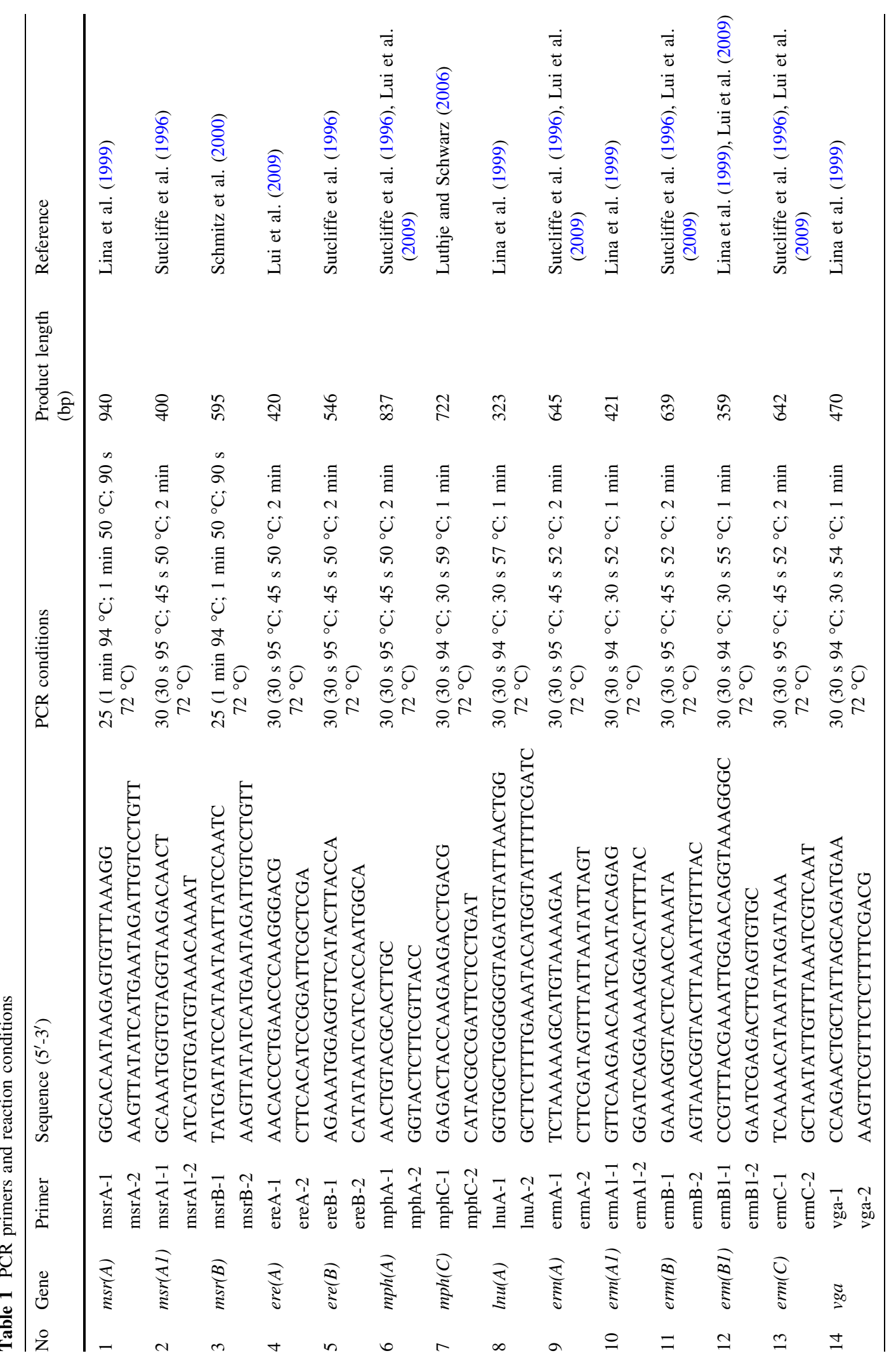




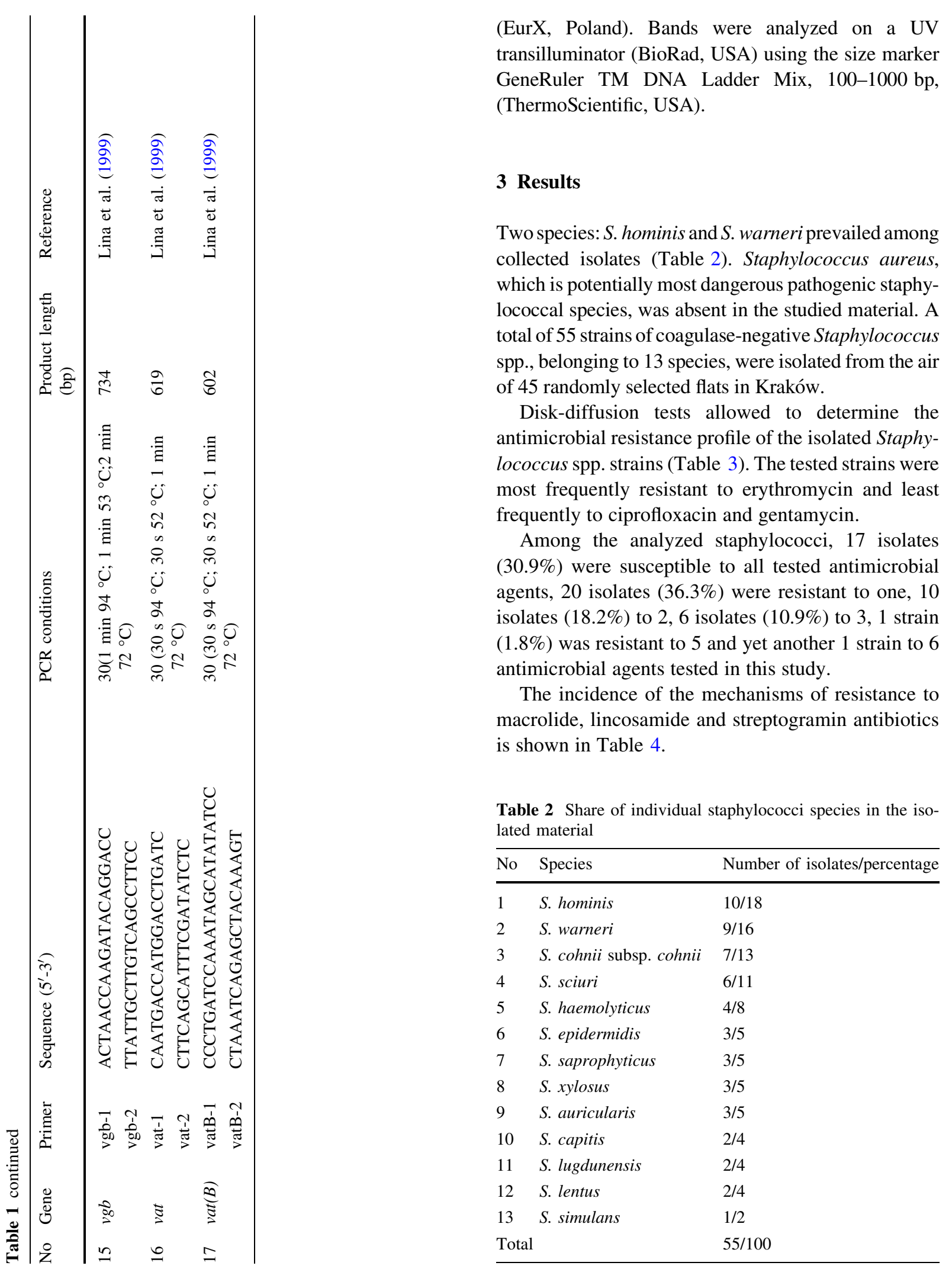


Table 3 Antimicrobial resistance of the studied Staphylococcus spp. strains

\begin{tabular}{ll}
\hline Antimicrobial agent & Number/percentage of resistant strains $(n=55)$ \\
\hline erythromycin & $35 / 63.6$ \\
tetracycline & $13 / 23.6$ \\
clindamycin & $11 / 20$ \\
cefoxitin & $4 / 7.3$ \\
trimethoprim/sulphamethoxazole & $3 / 5.5$ \\
ciprofloxacin & $2 / 3.6$ \\
gentamycin & $2 / 3.6$ \\
\hline
\end{tabular}

\begin{tabular}{ll}
\hline Mechanism of resistance & Number/percentage of strains $(n=55)$ \\
\hline MS $_{\mathrm{B}}$ & $21 / 38.2$ \\
Susceptible & $19 / 34.5$ \\
MLS $_{\mathrm{B}}$ constitutive & $8 / 14.5$ \\
MLS $_{\mathrm{B}}$ inducible & $5 / 9.1$ \\
Error in determination or L phenotype & $2 / 3.6$ \\
\hline
\end{tabular}

Table 4 Number/ percentage of strains resistant to $\mathrm{MLS}_{\mathrm{B}}$ antibiotics

Table 5 Prevalence of drug resistance genes in the tested strains
MLS macrolides, lincosamides and streptogramins B

\begin{tabular}{lll}
\hline Gene & Number/percentage of strains $(n=55)$ & Resistance to antibiotics \\
\hline$m p h C$ & $50 / 91$ & Macrolides \\
$m s r A 1$ & $41 / 75$ & Macrolides \\
ermB & $24 / 44$ & MLS \\
$m s r A$ & $18 / 32$ & MLS \\
$m s r B$ & $18 / 32$ & Macrolides \\
lnuA & $17 / 31$ & Lincosamides \\
ermC & $9 / 16$ & MLS \\
ermA & $3 / 5$ & MLS \\
ereA & $2 / 4$ & Macrolides \\
ereB & $1 / 2$ & Macrolides \\
ermA1 & $1 / 2$ & MLS \\
vga & $1 / 2$ & Streptogramins A \\
$m p h A$ & 0 & Macrolides \\
ermB1 & 0 & MLS \\
vgb & 0 & Streptogramins A i B \\
vat & 0 & Streptogramins A \\
vatB & 0 & Streptogramins A \\
\hline
\end{tabular}

Table 5 shows the results of PCR amplifications demonstrating the presence of genes conferring the resistance to MLS antibiotics. The data revealed that most of the analyzed Staphylococcus spp. isolates possessed $m p h(C)$ gene which confers the resistance to macrolides and is responsible for enzymatic inactivation of antibiotics by phosphotransferase. The second most frequent gene was $\operatorname{msr}(A 1)$, which confers the resistance to macrolides in staphylococci $\left(\mathrm{MS}_{\mathrm{B}}\right)$. Genes $\operatorname{erm}(B), \operatorname{msr}(A), m s r(B), \operatorname{lnu}(A), \operatorname{erm}, \operatorname{erm}(A)$, $\operatorname{ere}(A), \operatorname{ere}(B), \operatorname{erm}(A 1), v g a$ were present in less than half of the tested strains. On the other hand, the genes $m p h(A), \operatorname{erm}(B 1), v g b, v a t, v a t(B)$ were not found.

Among the tested isolates, one-identified as $S$. warneri-had as many as 7 resistance-determining genes, such as: $\operatorname{msr}(A), \operatorname{msr}(A 1), \operatorname{msr}(B), \operatorname{mph}(C)$, 
Table 6 Summary of antimicrobial resistance and the resistance-determining genes in the airborne staphylococci analyzed in this study

\begin{tabular}{|c|c|c|c|}
\hline No & Species & $\begin{array}{l}\text { Antimicrobial resistance (no. of strains with detected } \\
\text { mechanism)* }\end{array}$ & $\begin{array}{l}\text { Resistance-determining genes (no. of strains } \\
\text { with detected genes) }\end{array}$ \\
\hline 1. & S. hominis & $\begin{array}{l}\text { E (2); DA (2); TE (2); CIP (1); FOX (1); CN (1); } \mathrm{MLS}_{\mathrm{B}} \\
\text { constitutive (2) }\end{array}$ & $\begin{array}{l}m p h(C)(8) ; \operatorname{msr}(A)(1) ; \operatorname{msr}(B)(1) ; \operatorname{msr}(A 1)(5) ; \\
\quad \operatorname{ere}(A)(1) ; \operatorname{erm}(B)(5) ; \operatorname{erm}(C)(1) ; \operatorname{lnu}(A)(2) ;\end{array}$ \\
\hline 2. & S. warneri & $\begin{array}{l}\text { E (7); DA (1); TE (4); } \mathrm{MS}_{\mathrm{B}}(3) ; \mathrm{MLS}_{\mathrm{B}} \text { constitutive (1); } \\
\text { MLS }_{\mathrm{B}} \text { inducible (3) }\end{array}$ & $\begin{array}{l}m s r(A)(5) ; \operatorname{msr}(A 1)(7) ; \operatorname{msr}(B)(4) ; \operatorname{mph}(C)(8) ; \\
\quad \operatorname{lnu}(A)(4) ; \operatorname{erm}(B)(3) ; \operatorname{erm}(C)(2)\end{array}$ \\
\hline 3. & $\begin{array}{l}\text { S. cohnii subsp. } \\
\text { cohnii }\end{array}$ & E (6); DA (1); $\mathrm{MS}_{\mathrm{B}}(5) ; \mathrm{MLS}_{\mathrm{B}}$ constitutive (1) & $\begin{array}{l}\operatorname{msr}(A)(3) ; \operatorname{msr}(A 1)(6) ; \operatorname{msr}(B)(3) ; \operatorname{mph}(C)(7) ; \\
\operatorname{lnu}(A)(3) ; \operatorname{erm}(A)(1) ; \operatorname{erm}(B)(3) ; \operatorname{erm}(C)(1)\end{array}$ \\
\hline 4. & S. sciuri & $\begin{array}{l}\text { E (4); DA (2); TE (2); CIP (1); } \mathrm{MS}_{\mathrm{B}}(1) ; \mathrm{MLS}_{\mathrm{B}} \\
\text { constitutive (1); } \mathrm{MLS}_{\mathrm{B}} \text { inducible (2); error in } \\
\text { determination or L phenotype (1) }\end{array}$ & $\begin{array}{l}m s r(A)(1) ; \operatorname{msr}(B)(1) ; \operatorname{msr}(A 1)(4) ; \operatorname{mph}(C)(6) ; \\
\quad \operatorname{lnu}(A)(3) ; \operatorname{erm}(B)(4) ; \operatorname{erm}(C)(2)\end{array}$ \\
\hline 5. & S. haemolyticus & E (3); DA (1); $\mathrm{MS}_{\mathrm{B}}(2) ; \mathrm{MLS}_{\mathrm{B}}$ constitutive (1) & $\begin{array}{l}m s r(A)(2) ; m s r(A 1)(3) ; m s r(B)(2) ; m p h(C)(4) ; \\
\quad \operatorname{erm}(C)(1)\end{array}$ \\
\hline 6. & S. epidermidis & $\mathrm{E}(3) ; \mathrm{TE}(2) ; \mathrm{SXT}(1) ; \mathrm{MS}_{\mathrm{B}}(3)$ & $\begin{array}{l}m s r(A)(1) ; m s r(A 1)(3) ; m s r(B)(1) ; \operatorname{ere}(A)(1) ; \\
\quad m p h(C)(3)\end{array}$ \\
\hline 7. & $\begin{array}{l}\text { S. } \\
\quad \text { saprophyticus }\end{array}$ & $\mathrm{E}(2) ; \mathrm{DA}(1) ; \mathrm{MS}_{\mathrm{B}}(1)$ & $\operatorname{msr}(A 1)(1) ; \operatorname{mph}(C)(2) ; \operatorname{erm}(B)(2) ; \operatorname{erm}(C)(1)$ \\
\hline 8. & S. xylosus & E (3); DA (1); TE (1); $\mathrm{MS}_{\mathrm{B}}(2) ; \mathrm{MLS}_{\mathrm{B}}$ constitutive (1) & $\begin{array}{l}m s r(A)(2) ; \operatorname{msr}(A 1)(3) ; \operatorname{msr}(B)(2) ; \operatorname{mph}(C)(3) ; \\
\operatorname{lnu}(A)(1) ; \operatorname{erm}(A)(1) ; \operatorname{erm}(A 1)(1) ; \operatorname{erm}(B) \\
(1) ; \operatorname{erm}(C)(1)\end{array}$ \\
\hline 9. & S. auricularis & $\begin{array}{l}\text { E (2); DA (1); TE (1); FOX (1); CN (1); } \mathrm{MS}_{\mathrm{B}}(1) ; \mathrm{MLS}_{\mathrm{B}} \\
\text { constitutive (1) }\end{array}$ & $m s r(A)(3) ; m s r(A 1)(3) ; m s r(B)(3) ; m p h(C)(2)$ \\
\hline 10. & S. capitis & $\begin{array}{l}\text { E (1); DA (1); TE (1); SXT (1); } \mathrm{MS}_{\mathrm{B}} \text { (1); error in } \\
\text { determination or L phenotype (1) }\end{array}$ & $\begin{array}{l}\operatorname{msr}(A 1)(2) ; \operatorname{ere}(B)(1) ; \operatorname{mph}(C)(2) ; \ln u(A)(1) ; \\
\operatorname{erm}(B)(1)\end{array}$ \\
\hline 11. & S. lugdunensis & $\mathrm{S}$ & $\operatorname{msr}(A 1)(1) ; \operatorname{mph}(C)(2) ; \ln u(A)(1) ; \operatorname{erm}(B)(2)$ \\
\hline 12. & S. lentus & E (2); SXT (1); FOX (2); $\mathrm{MS}_{\mathrm{B}}(2)$ & $\begin{array}{l}\operatorname{msr}(A 1)(2) ; \operatorname{mph}(C)(2) ; \operatorname{lnu}(A)(2) ; \operatorname{erm}(A)(1) ; \\
\quad \operatorname{erm}(B)(2)\end{array}$ \\
\hline 13. & S. simulans & $\mathrm{S}$ & $\operatorname{msr}(A 1) ; \operatorname{msr}(B) ; \operatorname{mph}(C) ; \operatorname{erm}(B) ; \operatorname{vga}$ \\
\hline
\end{tabular}

* E-erythromycin; DA-clindamycin; TE-tetracycline; FOX-cefoxitin; CN-gentamycin; CIP-ciprofloxacin; SXTtrimethoprim/sulfamethoxazole; $\mathrm{MS}_{\mathrm{B}}$ - strains resistant to macrolides and streptogramins $\mathrm{B} ; \mathrm{MLS}_{\mathrm{B}}$ constitutive-strains showing constitutive type of resistance to macrolides, lincosamides and streptogramins B; MLS $_{\mathrm{B}}$ inducible—strains showing inducible type of resistance to macrolides, lincosamides and streptogramins B

$\operatorname{lnu}(A), \operatorname{erm}(B), \operatorname{erm}(C)$. In contrast, another strain also belonging to the same species did not have any of the analyzed genes. Most of the isolates, i.e., 17, had 4 genes conferring the resistance to MLS group of antibiotics, while further 12 strains had 2 different resistance genes. Table 6 summarizes the presented data concerning the species determination of airborne staphylococci, their antimicrobial resistance and the resistance-determining genes.

\section{Discussion}

The results of our study indicate that most of airborne staphylococci isolated from the studied flats possibly poses no threat to their healthy residents. Nevertheless, the presence of potentially pathogenic strainsalthough in small numbers-can cause infections particularly in elderly, children and in immunocompromised people (Gąska-Jędruch and Dudzińska 2009). The most numerous species in the analyzed material was S. hominis (18\%), which is usually isolated from human skin armpits, arms, legs and trunk. S. hominis usually does not cause serious infections in humans, but it is an opportunistic pathogen that can contribute to infections of hospitalized patients weakened by long-term pharmacological treatment (Jiang et al. 2012). On the other hand, studies conducted by Pastuszka et al. (2000) in flats of Upper Silesia (Poland) showed that the main bacterial 
species isolated from indoor air was $S$. epidermidis, which was present in $76 \%$ of studied flats constituting $14 \%$ of the total amount of bacteria. In our study, $S$. epidermidis isolates constituted only 5\% of all Staphylococcus species. The second most frequently isolated species in the presented research was $S$. warneri (16\%), which is a component of the human epithelium and mucous membrane microflora, but in some cases can be the cause of bacteriemia in longterm hospitalized patients (Campoccia et al. 2010). Another species among the identified staphylococci was S. cohnii subsp. cohnii (13\%), which may cause pneumonia, acute cholecystitis, endocarditis, bacteriemia and urinary tract infections. S. cohnii subsp. cohnii is mostly isolated in hospitals (Hu et al. 2014). The last most frequently observed staphylococci were the species defined as the one resistant to novobiocin-S. sciuri $(11 \%)$. It is regarded as a typical animal-related species, isolated from skin and mucous membranes, as well as from food products of animal origin. In humans, it can be present in nasopharynx, on skin and in urogenital system. Clinicians are increasingly interested in this species, as it has been recognized as one of the etiological factors of diseases such as endocarditis, peritonitis, septic shock, urinary tract infections and endophthalmitis (Dakić et al. 2005).

Most of the analyzed strains were resistant to erythromycin (63.6\%) and tetracycline $(23.6 \%)$, and least frequently to ciprofloxacin and gentamycin (3.6\% for both antimicrobials). Such large number of strains resistant to erythromycin may result from the fact that this is the oldest antibiotic from the group of macrolides that has been used in medical treatment (Markiewicz and Kwiatkowski 2012). Disk-diffusion tests demonstrated that $9.1 \%$ of the tested Staphylococcus strains showed inducible mechanism of resistance to macrolides, lincosamides and streptogramins B. In the case of constitutive mechanism, it was $14.5 \%$ of the tested strains. The results presented by Lina et al. (17) show that among coagulase-negative staphylococci the inducible mechanism was detected in $28.7 \%$ of strains, while constitutive one-in $36.6 \%$. On the other hand, Castro-Alarcon et al. (2011) reported that $47 \%$ of $S$. epidermidis strains tested in their study showed constitutive mechanism while inducible one was detected in $8 \%$ of strains. They also determined that $16 \%$ of strains were characterized by the $\mathrm{MS}_{\mathrm{B}}$ type of resistance, while $11 \%$ showed the resistance to lincosamides. In contrast, in our study the $\mathrm{MS}_{\mathrm{B}}$ type of resistance was found in as many as $38 \%$ of isolates.

Among the analyzed group of genes conferring the $\mathrm{MLS}_{\mathrm{B}}$ type of resistance were genes determining the resistance to macrolides, i.e., $m p h(C)$ and $m s r(A 1)$ - they were detected in more than half of the tested strains. Similar observations were reported by Lenart-Boroń et al. (2016) when analyzing the material of hospital-derived staphylococci with $m p h(C)$ gene observed in $62 \%$ of isolates and $m s r(A 1)$-in $89 \%$. It should, however, be noted that there were also some significant differences in the occurrence of other resistance-determining genes between the hospital strains tested by Lenart-Boron et al. (2016) and staphylococci analyzed in this study. Lenart-Boroń et al. (2016) detected erm(B1) (55\% of isolates) and $m p h(A)$ (9\% of isolates) genes, whereas they were not observed in our study. These differences could result from different origin of the analyzed strains, since hospital isolates can acquire various genes conferring antimicrobial resistance much more frequently (Murray 2007; Castro-Alarcon et al. 2011). The isolates analyzed in this study had a maximum of 7 resistance-determining genes at the same time, and some of them did not have any of the searched genes. Most often, individual strains had 4 resistance genes; however, having numerous resistance genes is not always beneficial for bacterial cells. When lacking antimicrobial pressure, the expression of genes determining such resistance is a significant effort for the cell metabolism and may reduce the growth of microorganisms (Marciniak 2008).

The increasingly detected, worrying process of antimicrobial resistance in Staphylococcus spp., which has been observed for many years, must be prevented. Currently, a number of educational activities are undertaken both in Poland and in other parts of the world, aiming at reducing abuse and misuse of antibiotics. This problem ceased to be the subject of interest of scientific community only, but it has become global and requires urgent intervention. This should be aimed at raising awareness of professionals, managers and public opinion about consequences and risks associated with uncontrolled use of antibacterial agents and methods to prevent drug resistance. Due to their global range, these issues have been considered as a priority in public health by a number of 
organizations and agencies around the world, e.g., by: the World Health Organization, the European Parliament, European Centre for Disease Prevention and Control, Centre for Diseases Control and Prevention, or Food and Drug Administration (CDC 2002; The European Commission 2001). The aim of all measures taken is to limit the uncontrolled overuse of antibiotics in medical and non-medical areas, prevent an increase in drug resistance and implement various programs in this regard. In addition, it is planned to develop a comprehensive system designed to stop the loss of antibiotic effectiveness in the treatment of infectious diseases as a result of the emergence and spreading of drug-resistant microorganisms, and to implement the principles of rational use of antibiotics.

\section{Conclusions}

The group of analyzed airborne staphylococci isolated from flats in Kraków was dominated by S. hominis and S. warneri species. In this group, the resistance to erythromycin and tetracycline was most frequently detected; however, $31 \%$ of strains were susceptible to all tested antimicrobial agents including cefoxitin, ciprofloxacin, erythromycin, gentamycin, clindamycin, tetracycline and trimethoprim/sulfamethoxazole. A large variation was found in the prevalence and composition of antibiotic resistance-determining genes among the tested strains. The most common antibiotic resistance genes were $m p h C$ and $m s r A l$, conferring the resistance to macrolides. The resulting antimicrobial resistance profile gives grounds to conclude that in the case of staphylococci infection, the use of antibiotics from basic antibiogram will be effective in therapy.

Acknowledgements This study was funded by the statutory measures of the University of Agriculture-Grant No. DS $3158 / \mathrm{KM} / 2014$ and by measures of the Centre for Microbiological Research and Autovaccines in Kraków.

Open Access This article is distributed under the terms of the Creative Commons Attribution 4.0 International License (http:// creativecommons.org/licenses/by/4.0/), which permits unrestricted use, distribution, and reproduction in any medium, provided you give appropriate credit to the original author(s) and the source, provide a link to the Creative Commons license, and indicate if changes were made.

\section{References}

Bartoszewicz-Potyrała, M., \& Przondo-Mordarska, A. (2002). Traits of coagulase-negative staphylococci determine pathogenicity. Advances in Microbiology, 41, 351-366. (in Polish).

Botelho, A. M. N., Nunes, Z. G., Asensi, M. D., Gomes, M. Z. R., Fracalanzza, S. E. L., \& Figueiredo, A. M. S. (2012). Characterization of coagulase-negative staphylococci isolated from hospital indoor air and a comparative analysis between airborne and inpatient isolates of Staphylococcus epidermidis. Journal of Medical Microbiology, 61, 1136-1145.

Butarewicz, A. (2005). Microbiological quality of air in the building of the Faculty of Construction and Environmental Engineering of the Białystok University of Technology. Annals of the National Institute of Hygiene, 56, 199-206.

Campoccia, D., Montanaro, L., Visai, L., Corazzari, T., Poggio, C., Pegreffi, F., et al. (2010). Characterization of 26 Staphylococcus warneri isolates from orthopedic infections. The International Journal of Artificial Organs, 33(9), $575-581$.

Castro-Alarcon, N., Ribas-Aparicio, R. M., Silva-Sanchez, J., Calderon-Navarro, A., Sanchez-Perez, A., Parra-Roja, I., et al. (2011). Molecular typing and characterization of macrolide licosamide and streptogramin resistance in Staphylococcus epidermidis strains isolated in a Mexican hospital. Journal of Medical Microbiology, 60, 730-736.

CDC. (2002). Staphylococcus aureus resistant to vancomycinUnited States. MMWR, 51(26), 565-567.

Chesneau, O., Ligeret, H., Hosan-Aghaie, N., Morvan, A., \& Dassa, E. (2005). Molecular analysis of resistance to streptogramin A compounds conferred by the vga proteins of staphylococci. Antimicrobial Agents and Chemotherapy, 49(3), 973-980.

Dakić, I., Morrison, D., Vuković, D., Savić, B., Shittu, A., Ježek, P., et al. (2005). Isolation and molecular characterization of Staphylococcus sciuri in the hospital environment. Journal of Clinical Microbiology, 43(6), 2782-2785.

Gaillot, O., Wetsch, M., Fortineau, N., \& Berche, P. (2000). Evaluation of CHROMagar Staph. aureus, a new chromogenic medium, for isolation and presumptive identification of Staphylococcus aureus from human clinical specimens. Journal of Clinical Microbiology, 38(4), 1587-1591.

Gąska-Jędruch, U., \& Dudzińska, M. (2009). Microbiological contaminants in indoor air. In J. Ozonek \& A. Pawłowski (Eds.), Polish environmental engineering five years after joining the european union (Vols. 2, 59, pp. 31-40). Lublin: PAS.

Górny, R. L., \& Dutkiewicz, J. (2002). Bacterial and fungal aerosols in indoor environment in Central and Eastern European countries. Annals of Agricultural and Environmental Medicine, 9, 17-23.

Hospodsky, D., Qian, J., Nazaroff, W. W., Yamamoto, N., Bibby, K., Rismani-Yazdi, H., et al. (2012). Human occupancy as a source of indoor airborne bacteria. PLoS ONE, 7(4), e34867. 
Hryniewicz, W. (2014). Breakpoint tables for interpretation of MICs and zone diameters, European Committee on Antimicrobial Susceptibility Testing (EUCAST), version 4.0.

Hu, X., Li, A., Lv, L., Yuan, C., Guo, L., Jiang, X., et al. (2014). High quality draft genome sequence of Staphylococcus cohnii subsp. cohnii strain hu-01. Standards in Genomic Sciences, 9, 755-762.

Irving, W., Ala'Aldeen, D., \& Boswell, T. (2008). Medical microbiology. Short lectures. Warsaw: PWN Polish Scientific Publisher.

Jiang, S., Zheng, B., Ding, W., Longxian, L., Jinru, J., Zhang, H., et al. (2012). Whole-genome sequence of Staphylococcus hominis, an opportunistic pathogen. Journal of Bacteriology, 194(17), 4761-4762.

Jo, W. K., \& Kang, J. H. (2006). Workplace exposure to bioaerosols in pet shop, pet clinics and flower garden. Chemosphere, 65, 1755-1761.

Kloos, W. E., \& Bannerman, T. L. (1994). Update on clinical significance of coagulase-negative staphylococci. Clinical Microbiology Reviews, 7, 117-140.

Kloos, W. E., \& Schleifer, K. H. (1975). Isolation and characterization of Staphylococci from human skin II. Descriptions of four new species: Staphylococcus warneri, Staphylococcus capitis, Staphylococcus hominis, and Staphylococcus simulans. International Journal of Systematic Bacteriology, 25, 62-79.

Leclerq, R. (2002). Mechanisms of resistance to macrolides and lincosamides: Nature of the resistance elements and their clinical implications. Clinical Infectious Diseases, 34(4), 482-492.

Lenart-Boroń, A., Wolny-Koładka, K., Stec, J., \& Kasprowicz, A. (2016). Phenotypic and molecular antibiotic resistance determination of airborne coagulase negative Staphylococcus spp. strains from healthcare facilities in southern Poland. Microbial Drug Resistance. doi:10.1089/mdr. 2015.0271.

Lina, G., Piémont, Y., Godail-Gamot, F., Bes, M., Peter, M. O., Gauduchon, V., et al. (1999). Involvement of PantonValentine leukocidin-producing Staphylococcus aureus in primary skin infections and pneumonia. Clinical Infectious Diseases, 29, 1128-1132.

Lui, Ch., Zhang, Z., Yuan, J., \& Guo, X. (2009). Antibiotic resistance of probiotic strains of lactic acid bacteria isolated from marketed foods and drugs. Biomedical and Environmental Sciences, 22, 401-412.

Luthje, P., \& Schwarz, S. (2006). Antimicrobial resistance of coagulase-negative staphylococci from bovine subclinical mastitis with particular reference to macrolide-lincosamide resistance phenotypes and genotypes. Journal of Antimicrobial Chemotherapy, 57, 966-969.

Marciniak, P. (2008). Bacterial resistance to antibiotics. Pharmaceutical newspaper, 12, 31-32. (in Polish).

Markiewicz, Z., \& Kwiatkowski, Z. (2012). Bacteria, antibiotics, resistance. Warsaw: PWN Polish Scientific Publisher. (in Polish).

Murray, P. E. (2007). Manual of clinical microbiology (9th ed.). Washington D.C.: ASM Press.

Pastuszka, J. S., Paw, U. K. T., Lis, D. O., Wlazło, A., \& Ulfig, K. (2000). Bacterial and fungal in indoor environment in Upper Silesia, Poland. Atmospheric Environment, 34, 3833-3842.

PN-Z-04008-08. (1989). Air purity protection-samplingsampling of atmospheric air (imission) for microbiological research by aspiration and sedimentation. Warsaw: Polish Committee for Standardization.

Schmitz, F., Sadurski, R., Kray, A., Mechthild, B., Geisel, R., Köhrer, K., et al. (2000). Prevalence of macrolide-resistance genes in Staphylococcus aureus and Enterococcus faecium isolates from 24 European university hospitals. Journal of Antimicrobial Chemotherapy, 45, 891-894.

Stogios, P. J., Kuhn, M. L., Evdokimova, E., Courvalin, P., Anderson, W. F., \& Savchenko, A. (2014). Potential for reduction of streptogramin A resistance revealed by structural analysis of acetyltransferase VatA. Antimicrobial Agents and Chemotherapy, 58(12), 7083-7092.

Sutcliffe, J., Grebe, T., Tait-Kamrat, A., \& Wondrack, L. (1996). Detection of erythromycin-resistant determinants by PCR. Antimicrobial Agents and Chemotherapy, 40(11), 2562-2566.

The European Commission. (2001). Communication from the commission on a community strategy against antimicrobial resistance (Brussels, 20.06.2001, COM 33 final, volume 1).

Żabicka, D., \& Hryniewicz, W. (2010). Recommendations for selection of tests for testing of bacterial susceptibility to antibiotics and chemotherapeutics 2010. Determination of susceptibility of Gram-positive cocci from the genus Staphylococcus. Warsaw: KORLD. 